\title{
PEMETAAN ERODIBILITAS TANAH DAN KORELASINYA TERHADAP KARAKTERISTIK TANAH DI DAS SERANG, KULONPROGO
}

\author{
Efrinda Ari Ayuningtyas ${ }^{1}$, Ainul Fahmi Nur Ilma ${ }^{2}$, Rindhang Bima Yudha ${ }^{3}$ \\ 1,2,3 Prodi Diploma PJSIG, Sekolah Vokasi, Universitas Gadjah Mada \\ Email : ${ }^{1}$ efrinda@mail.ugm.ac.id / eph.efrinda@gmail.com \\ Email : ${ }^{2}$ fahminurilma@gmail.com \\ Email : ${ }^{3}$ rindhangbiy@gmail.com
}

\begin{abstract}
Soil erosion was happened caused by many factors, such as rainfall intensity, soil erodbility, steepness and length of slope, land cover, and conservation practices. In other case, the soil properties also influence the vulnerability of soil to be detached. This soil properties characteristics is classified as soil erodibility. Erodibility factor (K) from the Universal Soil Loss Equation (USLE) in this study was the result of soil erodibility estimation or soil capability to be dispersed by rain. $K$ factor was affected by soil organic, soil permeability, soil structures, and soil textures. This study was contributed in Serang Watershed because of the main fuction of this watershed to supply water resources especially in Sermo Reservoir in Ngrancah Subwatershed. This reservoir was used to distribute water and irrigation to all Kulonprogo District and especially to keep the sustainability of sedimentation of soastal area di Glagah Beach. All of soil properties was collected in each landform of Serang Watershed and was analyzed by laboratory measurement. By using $K$ factor formula, the $K$ value can be estimated. Geographic Information System (GIS) tools were used to map and represent the spatial information of soil erodibility of Serang Watershed. The result of this study showed that the high value of $K$ factor was distributed in the area which has genesis of structural, denudated structural, and sedimented denudational. Furthermore, this study can be strived to analyze soil erosion hazard which was influenced by soil erodibility.
\end{abstract}

Keywords: erodibility, Serang Watershed, Kulonprogo

\section{PENDAHULUAN}

Erosi adalah proses penguraian material agregat tanah dalam bentuk yang kecil dan transportasi hasil penguraian tersebut melalui berbagai media seperti angin dan air (Belasri et al, 2017). Proses erosi menyebabkan kerusakan tanah dan perluasan dampak negatif pada lahan pertanian dan ekosistem hutan. Sedimentasi sebagai proses lanjutan dari erosi juga memberikan dampak buruk bagi pengairan dan sistem sungai, tingkat kekeruhan air danau meningkat, serta berpotensi meningkatkan abrasi di kawasan hilir yang berhadapan langsung dengan laut. Perkiraan intensitas kehilangan tanah adalah langkah awal untuk mengukur efektivitas konservasi suatu wilayah (Belasri et al, 2017).

Berbagai metode pengukuran dan perkiraan nilai erosi sudah diterapkan secara global (Jetten V., et al, 2006). Salah satu pemodelan erosi yang paling dasar dan banyak digunakan adalah Universal Soil Loss Equation (USLE) dan versi revisi (RUSLE), serta modifikasinya (MUSLE) (Wischmeier and Smith, 1978; Renard K.G., et al, 1997). Berdasarkan hasil penelitian sebelumnya, popularitas penggunaan metode USLE/RUSLE/MUSLE adalah karena beberapa hal berikut : 1) metode yang efisien, relatif mudah, dan dapat diterima publik; 2) kemampuannya mengakomodasi data dasar penyebab erosi; 3) kemudahan untuk diaplikasikan pada tingkat yang lebih luas seperti distribusi data yang bersifat global (Hann M.J, et al, 2006). Lebih lanjut Wischmeier and Smith (1978) menambahkan bahwa metode USLE mampu merangkum beberapa faktor yang mempengaruhi laju erosi seperti erosivitas hujan (R), erodibilitas tanah $(\mathrm{K})$, panjang lereng (L), sudut lereng (S), pengelolaan tanaman (C), dan praktik konservasi (P).

Zhang, et al (2007) menerangkan dalam penelitiannya bahwa erodibilitas tanah adalah faktor penentu kehilangan tanah. Melalui erodibilitas tanah, maka dapat diperkirakan laju erosi melalui karakteristik tanah (Tejada M, et al., 2006). Lebih lanjut Veihe (2002) menggambarkan sifat fisik, kimia, dan biologi tanah, serta mineral tanah dapat mempengaruhi nilai erodibilitas tanah. Tentu saja untuk dapat memprediksi besarnya laju erosi, nilai erodibilitas tanah tidak dapat berdisir sendiri. Nilai tersebut dapat dikorelasikan dengan curah hujan, laju aliran permukaan (runoff), dan infiltrasi tanah. Bagarello, V., et al, (2012) menyimpulkan bahwa nilai K merepresentasikan pengaruh profil dan karakteristik tanah terhadap 
kehilangan tanah. Di sisi lain Manyiwa T., et al (2013) juga menyimpulkan bahwa nilai K adalah salah satu indikator erosi karena menggambarkan kerentanan agregat tanah untuk terdispersi dalam bentuk yang lebih kecil dan terpindahkan oleh aliran air atau angin.

Ezeabasili, et.al (2014) menyimpulkan dalam penelitiannya bahwa erosivitas dan erosidibilitas berperan penting dan berkontribusi besar terhadap nilai kerentanan erosi di DAS Anambra. Penilaian erodibilitas sangat bergantung pada tekstur tanah. Hasil penilaian erodibilitas tersebut menyebutkan bahwa tekstur pasiran justru akan meningkatkan kerentanan tanah dalam proses penguraian (detachment), sedangkan tekstur lempungan akan memperkuat agregat tanah, sehingga akan mengurangi nilai erodibilitas.

Penelitian ini fokus pada Daerah Aliran Sungai (DAS) Serang di Kulonprogo yang merupakan satuan geomorfologi dengan karakteristik ekosistem yang khas karena meliputi kawasan pegunungan dengan topografi kasar hingga kepesisiran. DAS Serang mempunyai peran penting dalam mendukung kehidupan di dalamnya seperti sebagai sumber air masukan Waduk Sermo di DAS Ngrancah, sebagai jalur irigasi hingga ke Kecamatan Kalibawang, hingga ke muara yang berfungsi sebagai tempat sedimentasi yang menentukan kelangsungan pesisir Glagah. Sangat pentingnya fungsi dan ekosistem di dalam DAS Serang, maka penelitian yang mengkaji tentang erosi dinilai sangat menarik. Telah banyak dilakukan kajian yang berkaitan dengan laju dan tingkat bahaya erosi dengan menggunakan berbagai metode. Namun, penelitian ini fokus pada kajian karakteristik tanah yang merupakan faktor kerentanan tanah terhadap erosi. Tujuan utama dari kajian erodibilitas tanah di DAS Serang adalah (1) untuk mengetahui nilai erodibilitas tanah ditinjau dari berbagai sifat fisik, kimia, dan biologi tanah; dan (2) untuk memetakan distribusi nilai erodibilitas tanah di DAS Serang. Melalui hasil identifikasi dan pemetaan nilai erodibilitas, maka diharapkan dapat menjadi pedoman penilaian erosi untuk penelitian lebih lanjut.

\section{BAHAN DAN METODE PENELITIAN}

\section{Area Kajian}

Kajian erodibilitas pada penelitian ini difokuskan di DAS Serang, Kulonprogo (Gambar 2) berbatasan langsung dengan Kabupaten Purworejo, Jawa Tengah di sebelah barat. DAS Serang memiliki luas $218 \mathrm{~km}^{2}$ yang sebagian besar mencakup wilayah Kecamatan Kokap, Girimulyo, Pengasih, Nanggulan, Temon, Panjatan, dan Wates. Elevasi DAS Serang bervariasi dari 2 hingga 850 mdpal. Dengan variasi ketinggian tersebut, DAS Serang juga memiliki variasi relief dan topografi. Kenampakan relief berbukit dan bergunung dominan berada di DAS Serang bagian barat yang tepat berada di Kecamatan Kokap yang merupakan kecamatan dengan elevasi tertinggi di Kabupaten Kulonprogo. Bagian timur DAS Serang semakin landai dan bagian selatan adalah muara Sungai Serang yang bertopografi datar. Konfigurasi permukaan bumi yang beragam ini berpengaruh terhadap variasi curah hujan di DAS Serang. Curah hujan tahunan di DAS Serang mencapai lebih dari 750mm (Gambar 1). Jika kondisi tanah di DAS Serang adalah didominasi oleh tekstur lempung, maka dengan curah hujan dan topografi tersebut maka potensi erosi diperkirakan akan tinggi. Adapun penggunaan lahan di DAS Serang juga beragam dari lahan pertanian di kawasan dataran hingga hutan di topografi berbukit.

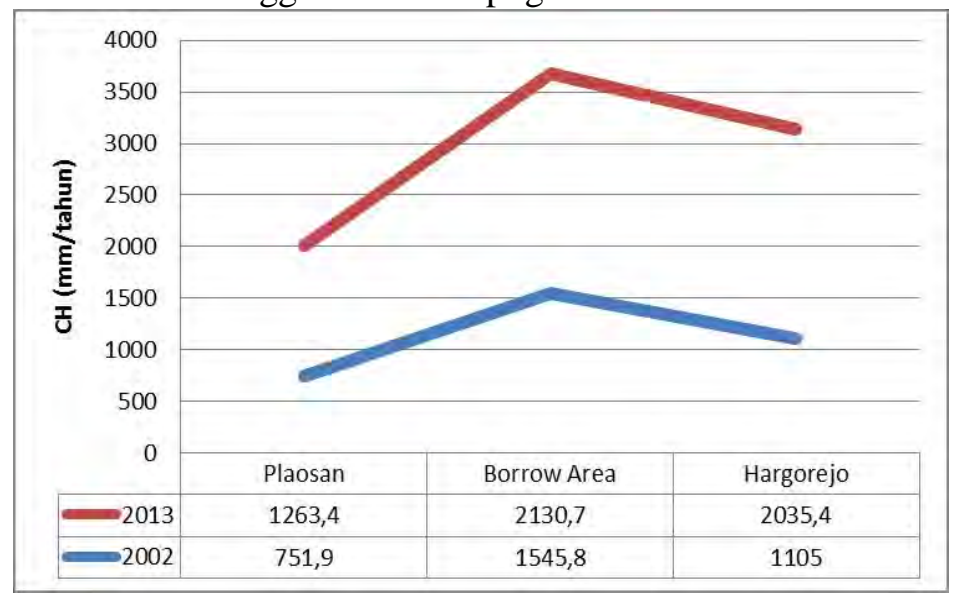

Gambar 1. Grafik Curah Hujan Tahunan di DAS Serang 


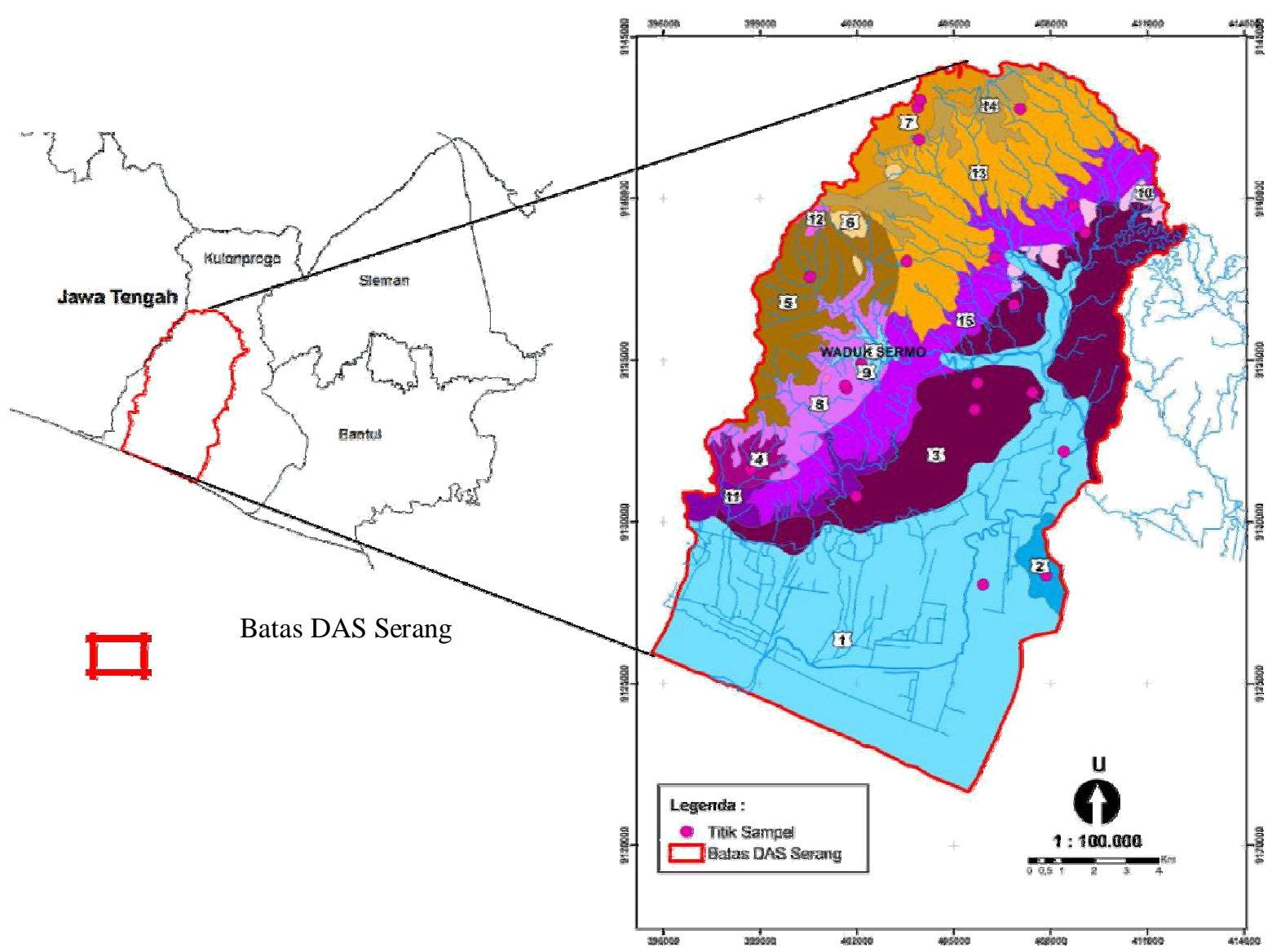

Gambar 2. Peta lokasi kajian DAS Serang

\section{Sampling Tanah dan Analisis}

Pada penelitian ini, penilaian erodibilitas tanah didasarkan pada persebaran jenis bentuklahan pada skala 1:100.000 di DAS Serang (Tabel 1). Bentuklahan menggambarkan secara spasial persebaran formasi geologi sebagai penyusun bentuklahan, topografi sebagai pemicu proses pembentukan bentuklahan, dan proses geologi yang bekerja pada kondisi geologi dan topografi tertentu yang menghasilkan bentukan khas dan beraneka ragam. Beberapa bentuklahan secara genesis yang telah diidentifikasi di DAS Serang antara lain struktural, denudasional, dan fluvial.

Pada kajian ini, pengambilan sampel tanah menggunakan metode random sampling pada setiap batas poligon bentuklahan. Pada setiap sampel tanah, analisis fisika dan kimia tanah meliputi tekstur tanah, bahan organik, dan permeabilitas tanah dilakukan di Laboratorium Geomorfologi dan Mitigasi Bencana Fakultas Geografi, Fakultas Geografi, Universitas Gadjah Mada. Tekstur tanah diklasifikasikan menjadi 12 kelas berdasarkan klasifikasi segitiga tekstur tanah yang meliputi lempung, lempung berpasir, lempung berdebu, lempung bergeluh, lempung geluh berdebu, lempung geluh berpasir, geluh, geluh berpasir, geluh berdebu, pasir, pasir bergeluh, serta debu. Adapun struktur tanah dapat diamati secara kualitatif di lapangan. Seluruh hasil analisis laboratorium menghasilkan nilai tertentu yang menentukan nilai erodibilitas. Adapun perhitungan nilai erododibilitas menggunakan rumus berikut (Wischmeier and Smith, 1978):

$$
\mathrm{K}=27,66 \mathrm{M}^{1,14} \times 10^{-8} \times(12-\mathrm{a})+0,043(\mathrm{~b}-2)+0,0033(\mathrm{c}-3)
$$

Keterangan :

$\mathrm{K}$ = erodibilitas tanah ( $\mathrm{Mg}$ ha $\mathrm{h} \mathrm{MJ}^{-1} \mathrm{ha}^{-1} \mathrm{~mm}^{-1}$ ); $\mathrm{M}=$ tekstur tanah; $\mathrm{a}=$ prosentase bahan organik; $\mathrm{b}=$ derajat struktur tanah; $\mathrm{c}=$ permeabilitas tanah 
Tabel 1. Bentuk lahan DAS Serang

\begin{tabular}{cll}
\hline Kode & \multicolumn{1}{c}{ Genesis } & \multicolumn{1}{c}{ Bentuklahan } \\
\hline 1 & (F) Fluvial & Dataran Fluvial Endapan Alluvium \\
\hline 2 & (F) Fluvial & Dataran Fluvial Formasi Sentolo \\
\hline 3 & (Dp) Denudasional Pengendapan & Perbukitan Denudasional Pengendapan Formasi Sentolo \\
\hline 4 & (Dp) Denudasional Pengendapan & Perbukitan Denudasional Pendendapan Andesit \\
\hline 5 & (S) Struktural & Kompleks Perbukitan Struktural Andesite \\
\hline 6 & (S) Struktural & Komp. Perbukitan Struktural Formasi Jonggrangan \\
\hline 7 & (S) Struktural & Komp. Puncak Perbukitan. Struktural Formasi Jonggrangan \\
\hline 8 & (Sd) Struktural Denudasional & Komp. Perbukitan Struktural Denudasional Andesit \\
\hline 9 & (Sd) Struktural Denudasional & Komp. Perbukitan Struktural Denudasional F. Nanggulan \\
\hline 10 & (Sd) Struktural Denudasional & Komp. Perbukitan Struktural Denudasional F. Sentolo \\
\hline 11 & (Dp) Denudasional Pengendapan & Perbukitan Denudasional Pengendapan F. Kebobutak \\
\hline 12 & (S) Struktural & Kompleks Puncak Perbukitan Struktural Andesite \\
\hline 13 & (S) Struktural & Komp. Perbukitan Struktural Formasi Kebobutak \\
\hline 14 & (S) Struktural & Kompleks Puncak Perbukitan Struktural F. Kebobutak \\
\hline 15 & (Sd) Struktural Denudasional & Komp. Perbukitan Struktural Denudasional F. Kebobutak \\
\hline
\end{tabular}

Sumber : Analisis Data, 2017

\section{HASIL DAN PEMBAHASAN}

\section{Parameter Erodibilitas Tanah}

Makna erodibilitas tanah sangat berbeda dengan istilah erosi tanah. Dalam pemodelan erosi, nilai erosi cenderung lebih menitikberatkan beberapa parameter seperti curah hujan, sudut dan kemiringan lereng, vegetasi penutup lahan, dan praktik konservasi lahan dibandingkan dengan karakteristik tanah (Belasri et al, 2017). Namun, secara fisik dan alami, proses erosi berkaitan erat dengan sifat tanahnya karena pada kondisi geografis apapun, tanah sebagai objek yang tererosi akan mengalami proses tersebut meskipun dalam instensitas yang berbeda.

Dengan lebih khusus, secara spasial, tanah memiliki karakteristik fisik dan kimia yang berbeda-beda tergantung pada sifat bahan induk pembentuk dan penyusun tanah. Tentunya jika dilihat dari aspek karakteristik tanah sendiri, dengan tidak mempertimbangkan faktor selain tanah, maka intensitas proses erosi akan berbeda pula. Hal yang membedakan inilah yang berkaitan dengan karakteristik tanah, disebut sebagai erodibilitas tanah (Wischmeier and Smith, 1978). Erodibilitas tanah secara umum dikontrol oleh empat faktor utama yaitu tekstur tanah, struktur tanah, bahan organik, dan permeabilitas tanah.

Tekstur tanah menggambarkan perbandingan ukuran pasir, debu, dan lempung dari suatu agregat tanah. Partikel pasir memiliki dimensi diameter berukuran 0,05 mm sampai $2 \mathrm{~mm}$, sedangkan debu berukuran 0,0002 sampai 0,05 mm, serta lempung berdimensi kurang dari 0,002 mm. Kajian sebelumnya oleh Zhao, et al (2011) membuktikan secara statistik bahwa partikel tanah berukuran 0,002 hingga 0,05 $\mathrm{mm}$ adalah kelompok partikel tanah yang paling mudah tererosi. Tekstur tanah mempengaruhi derajat perkolasi air ke dalam tanah dan stabilitas tanah. Tanah dengan kandungan pasir semakin banyak, akan memiliki pori-pori tanah yang besar, sehingga memudahkan air untuk mengalami infiltrasi dan perkolasi lebih cepat. Tanah semacam ini tidak rentan terhadap aliran permukaan (runoff) dan erosi. Sebaliknya, kondisi tanah di DAS Serang yang didominasi oleh lempung yang tinggi, maka pori tanah berkurang. Potensi aliran permukaan pada tanah tersebut akan meningkat. Adapun tanah dengan kandungan lempung yang tinggi, gaya kohesif menjadi lebih tinggi pula dan cenderung lebih stabil. Namun, karena sifat lempung yang mengikat air, justru akan meningkatkan potensi longsor terlebih apabila dipicu oleh kemiringan lereng terjal.

Duiker, et al. (2001) dalam penelitiannya menemukan bahwa kehilangan tanah berkorelasi negatif terhadap partikel lempung, tetapi berkorelasi positif terhadap tekstur pasir halus dan debu pasiran. Lebih lanjut Ogeen, et al (2006) menyimpulkan bahwa erodibilitas tanah bernilai rendah pada kondisi tanah berlempung karena partikel lempung dalam wujud agregat justru lebih tahan terhadap pukulan energi kinetik air hujan dan aliran permukaan. Dalam kajian penelitian ini menggambarkan bahwa DAS Serang didominasi oleh kelompok besar tekstur tanah lempung dan geluh lempung berdebu (Gambar 3). Kondisi tanah dengan dominan bertekstur lempung menunjukkan bahwa potensi erosi di DAS Serang diperkirakan 
bernilai sedang. Dari seluruh tahapan proses erosi, bentukan hasil erosi percik (splash erosion) adalah yang paling banyak ditemukan di daerah ini (Gambar 4). Adapun proses pelapukan batuan yang menunjukkan bahwa proses penelanjangan sebagai tahap awal erosi cukup dominan di DAS Serang (Gambar 4). Proses erosi lembar (sheet erosion) dan erosi alur (rill erosion) sebagai tahap erosi lanjutan belum banyak terjadi. Berdasarkan analisis laboratorium dan telaah pustaka sebelumnya, dominasi kandungan lempung dan kerentanan tanah terhadap erosi di DAS Serang adalah berkorelasi negatif. Hal ini bermakna bahwa parameter tekstur tanah lempung kurang memicu terjadinya erosi. Akan tetapi, dengan sifat lempung yang kuat menahan air akan memperbesar potensi gerakan massa tanah atau longsor (Gambar 4).

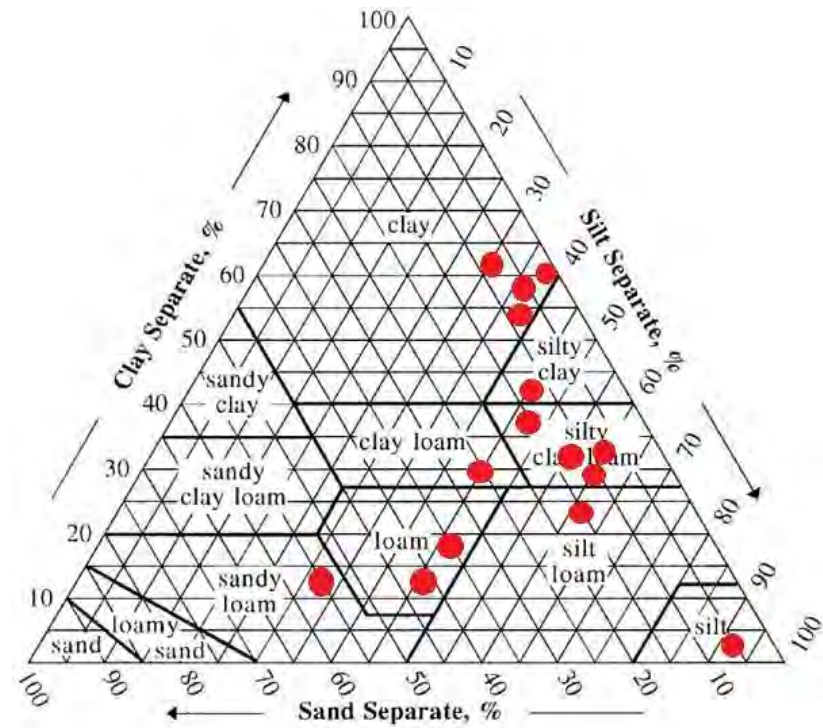

Gambar 3. Distribusi lempung, pasir, dan debu pada beberapa sampel tanah

Stuktur tanah merepresentasikan susunan tekstur tanah dalam agregat tanah. Dalam definisi lainnya menyebutkan bahwa struktur tanah berfungsi sebagai ukuran, bentuk, dan susunan pori dan partikel tanah,kapasitas meloloskan air dan zat terlarut, serta kemampuan untuk menjadi zona pertumbuhan akar tanaman. Secara sederhana dapat disimpulkan bahwa struktur tanah berperan penting dalam perkembangan tanah yang dipengaruhi oleh bahan organik, penggarapan tanah, dan keberadaan organisme tanah. Struktur tanah berkaitan dengan tekstur tanah. Semakin halur ukuran butir partikel tanah, maka semakin kecil ukura ukuran pori tanah, sehingga jarak antar butir menjadi semakin berdekatan. Kondisi semacam ini memiliki potensi untuk terjadi runoff semakin besar. Dengan kata lain, tanah menjadi tidak stabil pada tekstur lempung terutama ketika kondisi lembab atau basah karena air akan memenuhi pori tanah yang sempit. Struktur tanah di DAS Serang didominasi oleh tipe blocky atau columnar (Gambar 4). Kondisi struktur tanah semacam ini dicirikan dengan sifat tanahnya yang mudah menyerap air, tetapi sangat sedikit meloloskan air dan tidak mudah untuk ditembus akar. Tanah demikian cenderung bersifat lempung dengan drainase buruk. 

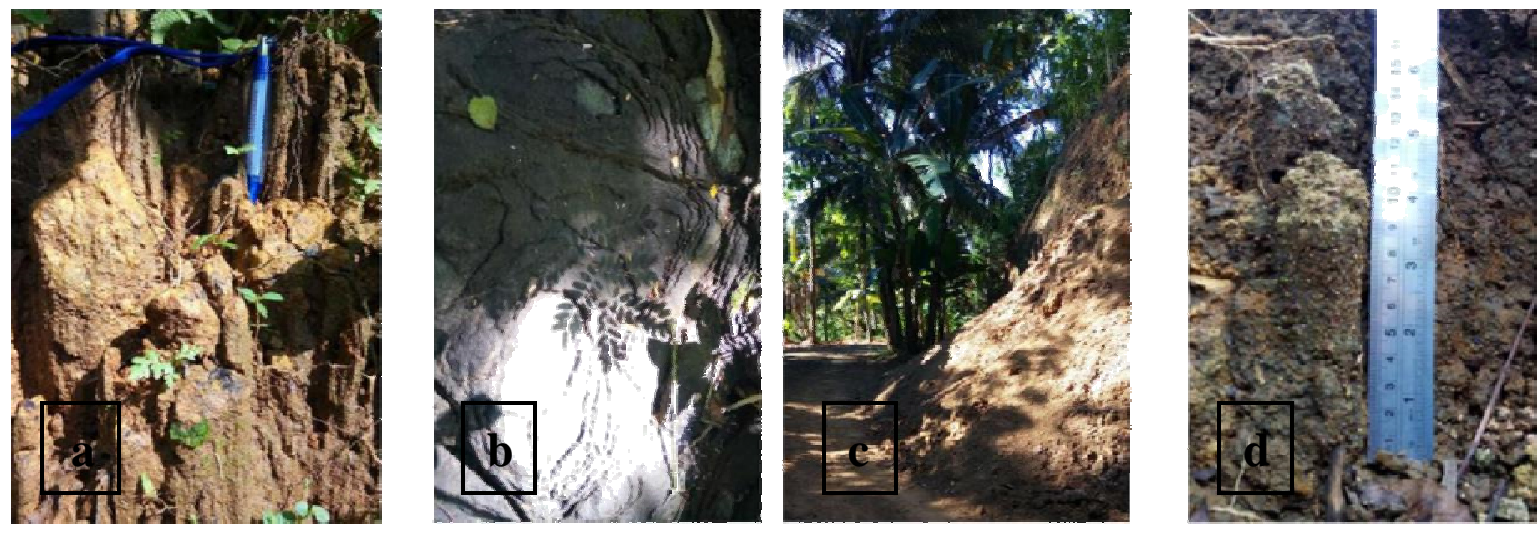

\section{Gambar 4. Splash Erosion (a); Pelapukan mengulit bawang (b); Kejadian longsor (c); dan Struktur Columnar (d)}

Unsur kimia yang turut berperan dalam memicu erosi adalah kandungan bahan organik. Ahan organik tanah berperan penting dalam pembentukan stabilitas agregat tanah. Bahan organik bereaksi positif dengan material lempung di dalam tanah untuk menyusun struktur tanah agar lebih kompak. Semakin kuat agregat tanah, maka semakin mudah tanah untuk diolah oleh alat pertanian. Bahan organik tidak hanya berperan menyusun struktur tanah pada tekstur lempungan, tetapi juga berperan penting pada tekstur pasiran. Tanah pasiran memiliki proporsi pori tanah yang besar dibandingkan dengan lempung $(>0,06 \mathrm{~mm})$ sebagai jalur sirkulasi udara dan air di dalam tanah. Namun, karena tanah pasiran miskin akan pori berukuran mikro, maka akan cenderung cepat mengalami kekeringan dan membutuhkan perlakuan irigasi yang rutin selama musim kemarau. Dengan tingginya kandungan bahan organik, maka mikropori akan meningkat, sehingga memaksimalkan kapasitas menyimpan air pada tanah pasiran.

FAO (2005) menyimpulkan bahwa bahan organik mampu memperbaiki struktur tanah, aerasi, infiltrasi air, ketahanan terhadap erosi, dan sebagai selimut tanah. Hasil analisis sampel tanah untuk parameter bahan organik, tidak ditemukan adanya korelasi antara persentase kandunganbahan organik dan tingkat erodibilitas. Hasil kajian penelitian ini lebih mengarah pada persentase kandungan bahan organik pada setiap sampel tanah yang mewakili bentuklahan. Wischmeier and Smith (1978) menegaskan bahwa pada kenyataanya, variasi nilai kandungan bahan organik tidak memiliki korelasi linier terhadap variasi erodibilitas. Salah satu penyebabnya adalah karena keterbatasan rentang nilai bahan organik di wilayah kajian (Stanchi, et.al., 2015).

Permeabilitas tanah berkorelasi terhadap tekstur tanah dan berbeda pada setiap jenis tanah. Permeabilitas tanah menggambarkan laju infiltrasi air di dalam profil tanah dalam kondisi jenuh air. Perbedaan tinggi tampungan air pada gelas ukur menunjukkan hubungan antara laju permeabilitas tanah dan tekstur tanah. Menurut hasil kajian Stanchi, et.al. (2015), laju permeabilitas tanah di DAS Serang tergolong lambat $(1-5 \mathrm{~mm} / \mathrm{jam})$ dan sangat lambat $(<1 \mathrm{~mm} / \mathrm{jam})$. Kondisi demikian menggambarkan tingginya kandungan lempung di dalam tanah, sehingga infiltrasi yang terjadi sangat kecil. Dampak dari kondisi tersebut adalah tingginya runoff dan cepatnya tanah untuk jenuh air. Akibat buruk yang mungkin terjadi adalah longsor jika dipicu oleh sudut dan kemiringan lereng yang curam.

\section{Erodibilitas Tanah}

Nilai erodibilitas dapat ditentukan dengan pendekatan data raster pada perangkat lunak ArcMap dan menghasilkan data spasial distribusi erodibilitas DAS Serang. Hasil pemetaan erodibilitas menunjukkan bahwa DAS Serang memiliki erodibilitas tanah yang relatif rendah hingga cukup rentan untuk mengalami erosi. Berdasarkan hasil pemetaan erodibilitas (Gambar 4), distribusi nilai K dengan kategori tinggi terdistribusi di bagian barat DAS Serang yang bertopografi kasar dan berbukit. Area tersebut memiliki kisaran nilai sebesar 0,10 sampai 0,15 $\mathrm{Mg}_{\text {ha h MJ }} \mathrm{MJ}^{-1} \mathrm{~mm}^{-1}$ diindikasikan oleh karakterstik tekstur tanah yang lempung bergeluh hingga lempung berpasir dengan permeabilitas tanah yang sangat lambat. 
Area yang memiliki kelas erodibilitas tinggi terdapat pada bentuklahan asal proses denudasional. Genesis bentuklahan asal proses denudasional didominasi oleh penelanjangan muka bumi berupa pelapukan batuan dan erosi hasil pelapukan. Contoh bentukan hasil pelapukan mengulit bawang pada Gambar 3 mengindikasikan adanya hubungan antara curah hujan, topografi, dan genesis bentuklahan.

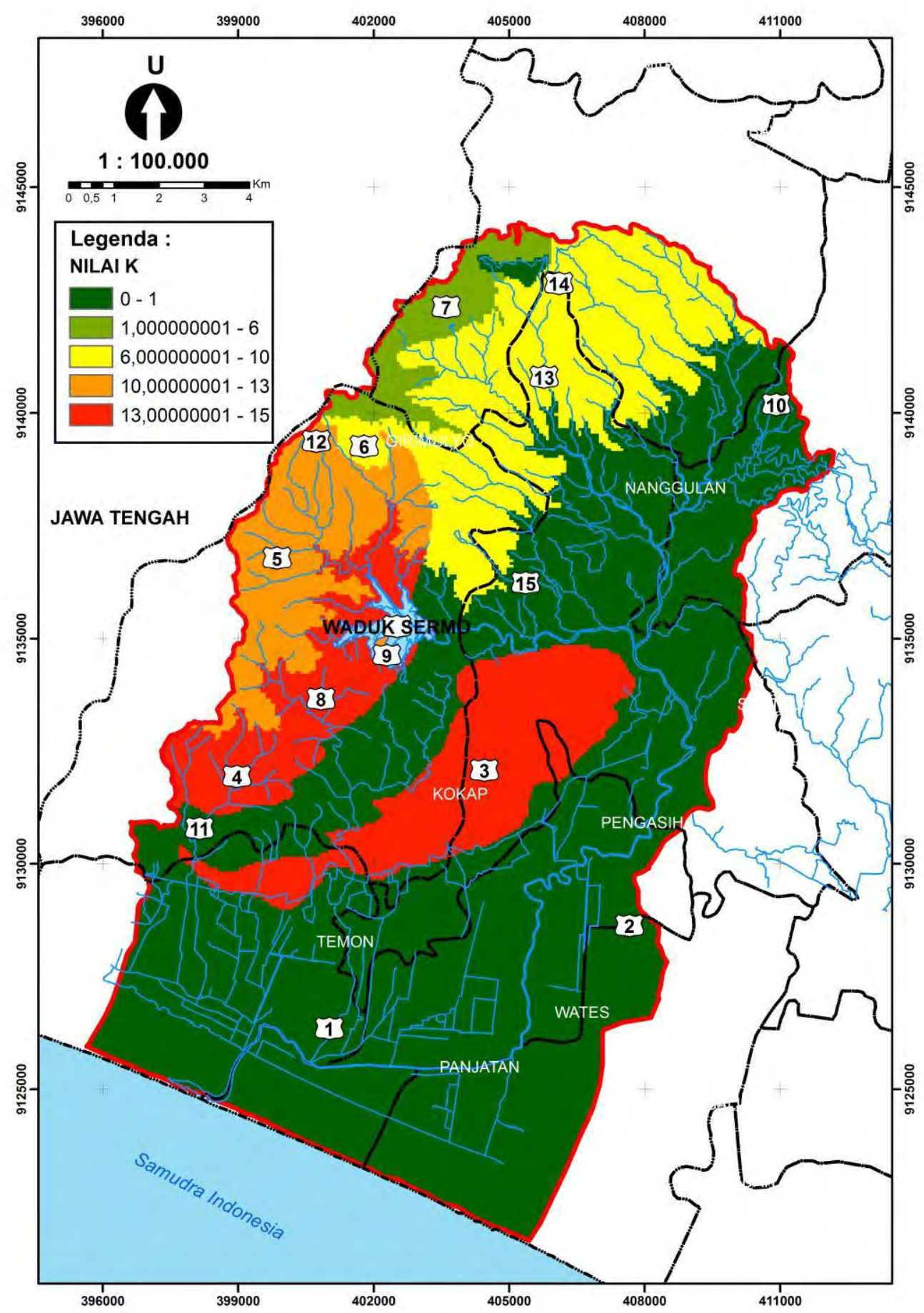

Gambar 4 Peta Faktor Erodibilitas DAS Serang 
Proses denudasional pada bentuklahan yang bernilai K tinggi berkorelasi dengan kondisi topografi yang berbukit dengan curah hujan yang tinggi. Dari hasil pengamatan lapangan, bentukan erosi lembar dan alur tidak banyak ditemukan pada bentuklahan bernilai K tinggi. Namun, tingginya proses pelapukan batuan sebagai tahap awal denudasional yang diindikasikan oleh tingkat kekuatan batuan yang lemah (hancur dipukul dengan palu geologi berkekuatan rendah), menunjukkan bahwa potensi untuk terjadi erosi cukup tinggi di wilayah ini. Olvmo (2010) menegaskan tentang hal ini bahwa pelapukan secara alami akan menurunkan kekuatan batuan dan meningkatkan permeabilitas tanah permukaan. Akibatnya, kondisi ini akan meningkatkan kerentanan terhadap longsor dan mudah untuk tererosi. Hasil analisis karakteristik tanah dan erodibilitas tanah DAS Serang dalam penelitian ini ditunjukkan oleh Tabel 2 berikut :

Tabel 2 Nilai erodibilitas tanah (K) pada berbagai jenis bentuklahan

\begin{tabular}{|c|c|c|c|c|c|c|c|c|}
\hline \multirow{2}{*}{ Kode } & \multirow{2}{*}{ Bentuk lahan } & \multicolumn{3}{|c|}{ Tekstur Tanah (\%) } & \multirow{2}{*}{$\begin{array}{r}\text { BO } \\
(\%)\end{array}$} & \multirow{2}{*}{$\begin{array}{l}\text { Struktur } \\
\text { Tanah }\end{array}$} & \multirow{2}{*}{ Permeabilitas } & \multirow{2}{*}{$\begin{array}{l}\text { Erodibilitas } \\
\quad(\mathrm{K})\end{array}$} \\
\hline & & Pasir & Debu & Lempung & & & & \\
\hline 1 & $\begin{array}{l}\text { Dataran Fluvial Endapan } \\
\text { Alluvium }\end{array}$ & 6,89 & 45,45 & 0,52 & 0,73 & $\begin{array}{l}\text { Remah } \\
\text { (Lemah) }\end{array}$ & 0,052 & 0,057 \\
\hline 2 & $\begin{array}{l}\text { Dataran Fluvial Formasi } \\
\text { Sentolo }\end{array}$ & 16,01 & 44,77 & 39,22 & 2,19 & $\begin{array}{l}\text { Remah } \\
\text { (Kuat) }\end{array}$ & 0,033 & 0,127 \\
\hline 3 & $\begin{array}{l}\text { Perbukitan Denudasional } \\
\text { Pengendapan Formasi Sentolo }\end{array}$ & 12,46 & 55,89 & 31,65 & 2,34 & $\begin{array}{c}\text { Gumpal } \\
\text { (Kuat) }\end{array}$ & 0,044 & 0,136 \\
\hline 4 & $\begin{array}{l}\text { Perbukitan Denudasional } \\
\text { Pendendapan Andesit }\end{array}$ & 35,32 & 46,96 & 17,72 & 1,4 & $\begin{array}{c}\text { Remah } \\
\text { (Lemah) }\end{array}$ & 0,022 & 0,078 \\
\hline 5 & $\begin{array}{l}\text { Kompleks Perbukitan } \\
\text { Struktural Andesite } \\
\end{array}$ & 8,62 & 36,76 & 54,62 & 1,42 & $\begin{array}{c}\text { Lempeng } \\
\text { (Kuat) }\end{array}$ & 0,026 & 0,113 \\
\hline 6 & $\begin{array}{l}\text { Komp. Perbukitan Struktural } \\
\text { Formasi Jonggrangan }\end{array}$ & 2,82 & 37,41 & 59,77 & 0,8 & $\begin{array}{l}\text { Gumpal } \\
\text { (Lemah) }\end{array}$ & 0,029 & 0,110 \\
\hline 7 & $\begin{array}{l}\text { Komp. Puncak Perbukitan } \\
\text { Struktural Formasi } \\
\text { Jonggrangan }\end{array}$ & | 2,82 & 37,41 & 59,77 & 0,8 & $\begin{array}{l}\text { Gumpal } \\
\text { (Lemah) }\end{array}$ & 0,029 & 0,110 \\
\hline 8 & $\begin{array}{l}\text { Komp. Perbukitan Struktural } \\
\text { Denudasional Andesit }\end{array}$ & 54,84 & 34,41 & 10,75 & 0,7 & $\begin{array}{l}\text { Remah } \\
\text { (Cukup } \\
\text { Kuat) } \\
\end{array}$ & 0,104 & 0,097 \\
\hline 9 & $\begin{array}{l}\text { Komp. Perbukitan Struktural } \\
\text { Denudasional F. Nanggulan } \\
\end{array}$ & 41,23 & 46,88 & 11,89 & 1,41 & $\begin{array}{c}\text { Remah } \\
\text { (Lemah) }\end{array}$ & 0,465 & 0,086 \\
\hline 10 & $\begin{array}{l}\text { Komp. Perbukitan Struktural } \\
\text { Denudasional F. Sentolo }\end{array}$ & 8,97 & 31,25 & 59,78 & 0,77 & $\begin{array}{l}\text { Gumpal } \\
\text { (Lemah) }\end{array}$ & 0,081 & 0,110 \\
\hline 11 & $\begin{array}{l}\text { Perbukitan Denudasional } \\
\text { Pengendapan F. Kebobutak }\end{array}$ & 26,33 & 44,35 & 29,32 & 0,72 & $\begin{array}{c}\text { Remah } \\
\text { (Lemah) }\end{array}$ & 0,049 & 0,104 \\
\hline 12 & $\begin{array}{l}\text { Kompleks Puncak Perbukitan } \\
\text { Struktural Andesite }\end{array}$ & 20,9 & 56,45 & 22,65 & 0,72 & $\begin{array}{c}\text { Lempeng } \\
\text { (Kuat) }\end{array}$ & 0,102 & 0,158 \\
\hline 13 & $\begin{array}{l}\text { Komp. Perbukitan Struktural } \\
\text { Formasi Kebobutak }\end{array}$ & 11,93 & 55,08 & 32,99 & 1,48 & $\begin{array}{l}\text { Remah } \\
\text { (Kuat) }\end{array}$ & 0,025 & 0,138 \\
\hline 14 & $\begin{array}{l}\text { Kompleks Puncak Perbukitan } \\
\text { Struktural F. Kebobutak }\end{array}$ & 14,34 & 54,04 & 31,62 & 0,73 & $\begin{array}{l}\text { Lempeng } \\
\text { (Kuat) }\end{array}$ & 0,014 & 0,143 \\
\hline 15 & $\begin{array}{l}\text { Komp. Perbukitan Struktural } \\
\text { Denudasional F. Kebobutak }\end{array}$ & 14,84 & 43,38 & 41,78 & 1,49 & $\begin{array}{c}\text { Gumpal } \\
\text { (Kuat) }\end{array}$ & 0,053 & 0,126 \\
\hline
\end{tabular}

Sumber : Hasil Analisis, 2017

Kondisi berbeda terdapat pada bentuklahan asal proses fluvial dan struktural yang memiliki nilai erodobilitas sedang dan rendah. Nilai K berkisar antara 0,01 sampai 0,08 Mg ha h $\mathrm{MJ}^{-1} \mathrm{ha}^{-1} \mathrm{~mm}^{-1}$. Karakteristik tekstur tanah pada bentuklahan ini adalah geluh dan lempung dengan permeabilitas lambat. Kedua hal terkait stabilitas agregat dan erodibilitas sangat dipengaruhi oleh kandungan bahan organik (Stanchi, et.al., 2015). Di sisi lain, bahan organik tanah berkorelasi terhadap penutup lahan, pengaruh perbedaan morfologi, dan faktor iklim (Oueslati et al., 2013). Namun, penelitian ini tidak menelaah lebih jauh tentang pengaruh hal tersebut, sehingga nilai K murni diperoleh berdasarkan sifat asli tanah sampel. 
Paradigma definisi erosi dalam penelitian ini mengacu pada konsep USLE yang mengasumsikan bahwa pemodelan erosi tersebut hanya pada tanah permukaan. Poch dan Antunez (2010) dalam penelitiannya menyebutkan bahwa bahan organik yang paling banyak ditemukan pada horizon tanah atas. Barthès et al. (1999) dalam kajiannya juga menemukenali hubungan antara kerentanan tanah terhadap erosi dengan stabilitas agregat tanah lapisan atas. Gaya kohesi antara material lempung dan bahan organik menyebabkan struktur tanah menjadi lebih kompak, sehingga tidak mudah pecah oleh hantaman energi kinetik dari air hujan.

\section{KESIMPULAN}

Erodibilitas tanah berkaitan erat dengan kehilangan tanah melalui pendekatan formula yang mengkombinasikan nilai tekstur tanah, struktur tanah, bahan organik, dan permeabilitas tanah. Tingginya kandungan lempung dalam tanah di DAS Serang, menyebabkan agregat tanah lebih kuat, sehingga mengurangi kerentanan terhadap erosi. Nilai erodibilitas tanah mentransformasikan parameter karakteristik tanah dan tidak mempertimbangkan faktor kelerengann, hujan, penutup lahan, serta praktik konservasi. Hasil penilaian dan pemetaan erodibilitas pada masing-masing bentuklahan di DAS Serang menggambarkan sifat tanah yang memiliki kecenderungan untuk rentan atau justru tahan terhadap bahaya erosi. Secara spasial, DAS Serang mempunyai variasi nilai erodibilitas, tetapi dari hasil analisis menunjukkan bahwa pada umumnya tanah lempung mendominasi dan mempengaruhi rendahnya erodibilitas tanah. Sifat tanah lempungan di area ini cenderung untuk rentan terhadap gerakan massa tanah seperti longsor karena sifat tanahnya yang tidak mudah meloloskan air. Perlu adanya penelitian lanjutan untuk lebih melengkapi hipotesis dan kesimpulan dari hasil nilai erodibilitas di DAS Serang agar lebih bermanfaat dalam upaya pengelolaan lingkungan.

\section{UCAPAN TERIMA KASIH}

Penelitian ini berjalan dengan baik dan menghasilkan nilai erodibilitas yang mendekati kondisi nyata di lapangan. Peneliti dan penulis mengucapkan terima kasih kepada segenap pihak yang terlibat dalam penyelesaian penelitian yaitu warga Desa Hargomulyo, Kecamatan Kokap dan Pengelola Laboratorium Geomorfologi dan Mitigasi Bencana Fakultas Geografi, UGM.

\section{DAFTAR PUSTAKA}

Jetten, V., \& Favis-Mortlock, D. 2006. Modelling soil erosion in Europe. In: J. Boardman, \& J. Poesen (Eds.), Soil erosion in Europe (pp. 695-716). Chichester, England: John Wiley \& Sons Ltd.

Wischmeier, W.H., Smith, D.D., 1978. Predicting rainfall erosion losses: a guide to conservation planning. U.S. Dept. Agric., Agric. Handb., 537.

Renard K.G., G.R. Foster G.A. Weesies D.K., McCool., Yoder D.C., Guide. Conserv. Plan. RUSLE. 1997.

Hann, M.J., and R.P.C. Morgan. 2006. Evaluating erosion control measures for biorestoration between the time of soil reinstatement and vegetation establishment. Earth Surface Processes and Landforms 31: 589-597.

Zhang ZG, Fan BE, Bai WJ, Jiao JY 2007. Soil anti-erodibility of plant communities on the removal lands in hilly-gully region of the Loess Plateau. Sci. Soil Water Conserv., 5:7-13 (in Chinese).

Veihe, A. (2002). The spatial variability of erodibility and its relation to soil types: a study from northern Ghana. Geoderma, 106: 101-120.

Bagarello, V., Di Stefano, C., Ferro, V., Giordano, G., Iovino, M. and Pampalone, V. 2012. Estimating the USLE the Soil Erodibility Factor in Sicily, South Italy. Applied Engineering in Agriculture, 28, 199-206. 
Manyiwa, T. and Dikinya, O. 2013. Using Universal Soil Loss Equation and Soil Erodibility Factor to Assess Soil Erosion in Tshesebe Village, Northeast Botswana. African Journal of Agricultural Research, 8, 4170-4178.

Zhao P, Shao MA, Omran W, Amer AM 2011. Effects of erosion and deposition on particle size distribution of deposited farmland soils on the Chinese Loess Plateau. Revista Brasileira de Ciência do Solo 35: 2135-2144. - doi: 10.1590/S0 100-06832011000600028

Duiker S.W., Flanagan D.C., Lal R., Catena. Erodibility and infiltration characteristics of five major soils of southwest Spain. 45. 2001. 103-121.

Geen, A. T., Elkins, R., Lewis, D. 2006. Erodibility of agricultural soils with examples in Lake and Mendocino counties Oakland. University of California, Division of Agriculture and Natural Resources. Publication Number: 8194.

Tejada, M. and Gonzalez, J.L. 2006. The Relationships Between Erodibility and Erosion in a Soil Treated with Two Organic Amendments. Soil and Tillage Research, 91, 186-198.

Belasri, A., A. Lakhouili, O. Iben Halima. 2017. Soil erodibility mapping and its correlation with soil properties of Oued El Makhazine watershed, Morocco. JMES, 2017, 8 (9), pp. 3208-3215

Olvmo, M. 2010. Review of Denudation Processes and Quantification of Weathering and Erosion Rates at A 0.1 to 1 MA Time Scale. ISSN 1404-0344 SKB TR-09-18

Stanchi, S., G. Falsone. 2015. Soil aggregation, erodibility, and erosion rates in mountain soils (NW Alps, Italy). Solid Earth, 6, 403-414, 2015 doi:10.5194/se-6-403-2015

Barthès, B., Albrecht, A., Asseline, L., De Noni, G., and Roose, E.: Relationships between soil erodibility and topsoil aggregate stability or carbon content in a cultivated Mediterranean highland (Aveyron, France), Commun. Soil Sci. Plant, 30, 1929-1938, 1999.

Poch, R. M. and Antunez, M.: Aggregate development and organic matter storage in Mediterranean mountain soils, Pedosphere, 20, 702-710, doi:1 0.1016/S1002-0160(12)60079-4, 2010. 